\title{
SUÇA SÜRÜKLENEN ÇOCUKLAR İLE SUÇA SÜRÜKLENMEYEN ÇOCUKLARIN ALGILADIKLARI ANNE VE BABA TUTUMLARI ILE EBEVEYN BAĞLANMA STILLERININ KARŞILAŞTIRILARAK INCELENMESI
}

\author{
THE COMPARATIVE ANALYSIS OF THE PERCEPTIONS OF FATHER AND MOTHER \\ ATTITUDES AND PARENTAL ATTACHMENT STYLES OF DELINQUENT \\ CHILDREN AND NOT DELINQUENT CHILDREN
}

\author{
Rabia AFŞİN ${ }^{1}$ - Ayşe Dilek ÖĞRETİR ÖZÇELIKK ${ }^{2}$
}

\begin{abstract}
$\ddot{\mathbf{O} z}$
Bu çalışmada 12-18 yaş grubu suça sürüklenen çocuklar ile aynı yaş grubu suça sürüklenmeyen çocukların algıladıkları anne ve baba tutumları ile ebeveyne bağlanma stilleri incelenmiştir. Araştırmanın örneklemini Diyarbakır ve Şanlıurfa ilinde bulunan 102 suça sürüklenen çocuk ile 108 ortaöğretim kurumuna devam eden çocuk oluşturmuştur. Araştırmada çocukların algıladıkları anne ve baba tutumlarını ölçmek için 'Çocuk Yetiştirme Stilleri Ölçeği (ÇYSÖ)', bağlanma stillerini ölçmek amaciyla 'Ebeveyn ve Arkadaşlara Bağlanma Envanteri (EABE)' kullanılmıştır. Bu çalışmada elde edilen veriler SPSS Statistics 23 paket programı ile analiz edilmiştir. Sayısal değişkenlerin normal dağılımdan gelme durumları araştırılırken birim sayıları nedeniyle Kolmogorov Smirnov'dan yararlanılmıştır. Çalışmadaki değişkenler normal dağılmadığ i için parametrik olmayan istatistiksel yöntemlerden yararlanılmıştır. Bağımsız sayısal değişkenler arasındaki iliş̧ki Spearman's Rho Korelasyon Katsayısı ile incelenmiştir. İki bağımsız grup arasındaki farklılıklar incelenirken Mann Whitney U Testinden yararlanılmıştır. İkiden fazla bağımsız grup arasındaki farklılık ise Kruskal Wallis Testi analizi ile incelenmiştir. İki bağımsız kategorik değişken arasındaki ilişki Ki Kare Testi ile analiz edilmiş̧ir. Sonuçlar yorumlanırken anlamlılık düzeyi olarak 0,05 kullanılmıştır. Araştırmada elde edilen bulgulara göre, suça sürüklenen çocuklar ile suça sürüklenmeyen çocukların anne ve baba tutumları ile bağlanma stilleri açısından anlamlı farklılıklar vardır.
\end{abstract}

Anahtar Kelimeler: Suç, Ergenler, Anne Baba Tutumu, Bağlanma

\begin{abstract}
In this study, the 12-18 age group children who are the delinquent versus the children in the same age group who are not the delinquent were comparatively analyzed in terms of their perceptions about their mother and father attitudes and their attachment styles. The sample of the survey consists of 102 children who are delinquent and 108 children who are not delinquent and in the middle schools living in Diyarbakir and Sanliurfa city centers. In order to measure children's perceptions of their mother and father attitudes, the 'Parental Attitude Scale' (PAS) was used. In addition, in order to measure attachments style, the 'Inventory of Parent and Peer Attachment Short Version (IPPA-C) were implemented. Data of the survey were analyzed with IBM SPSS Statistics 23. Kolmogorov-Smirnov test was used if the number of units and researched state of variables arise from the normal distribution. In the study, because the data are not normally distributed, non-parametric statistical analyses are used. The relationship between independent variables is analyzed by using Spearman's Rho Correlation Co-efficient. When we analyze two independent variables, we apply Mann-Whitney U Test. When we analyze more than two independent variables, we use Kruskal-Wallis test. When we look at two independent categorical variables, we use Chi-square test. For all significance level, we determine 0,05. According to the results of this study, there were statistically significant differences between delinquent adolescents and nondelinquent adolescents about their perceived parental styles and parental attachment styles.
\end{abstract}

Keywords: Crime, Adolescents, Parental Attitudes, Attachment

${ }^{1}$ Gazi Üniversitesi, rabia21d@hotmail.com

2 Doç.Dr., Gazi Üniversitesi, Eğitim Fakültesi , dilekogretir@gmail.com

Makale Geliş Tarihi:02/22/2017 - Makale Kabül Tarihi:16/12/2018 - Makale Türü: Araştırma DOI:10.17755/esosder.294032 


\section{GIRIŞ}

Toplum bilimcilere göre suç, bireyin içinde yaşadığı toplumun, toplumsal ve kültürel şartlarının kötü etkileri sonucu, bireyi birlikte yaşadığı toplumdaki diğer bireylerin karşısına çıkaran bir çatışma ürünüdür. Ceza hukukçularına göre ise suç, yasalarca yapılması yasaklanan ve cezalandırılan eylemlerdir. Suç evrensel bir sorun olup, insanların toplu halde yaşamasından bu yana var olan bir problemdir. Bireyin içinde bulunduğu toplumda suça yönelten birçok sebeple iç içe yaşama zorunluluğu ve sosyalleşmede gerekli olan diğer bireyleri model alma ve öğrenme süreci, bireyin suç işlemesinde ve potansiyel suçlu olmasında çoğu kez etkin bir rol oynamaktadır (Baltacı, 2011). Tarihin her döneminde yetişkinlerde olduğu gibi çocuklarda da suçluluk davranışı görülmektedir. 17. yüzyıla kadar yetişkinlere uygulanan cezalar çocuklara da uygulanmaktayken, 18. yüzyıldan itibaren humanizm akımının etkisiyle çocukların ayrıcalıklı olması yönünde adım atılmıştır (Ward, 2010).

Tüm dünyada olduğu gibi ülkemizde de çocuk suçluluğu, sosyolojik ve hukuksal açıdan asrın en önemli sorunlarından biridir. Ülkemizde ve dünyada çocuk suçluların sayısında giderek bir artış meydana gelmektedir. Çocuk suçluluğunun nedenleri, sosyoloji, psikoloji, biyoloji ve hukuk gibi farklı disiplinlerin araştırma konusu durumundadır. Çocuk suçluluğunda kalıtsal ve bedensel özelliklerin yanı sıra özellikle aile, okul, arkadaşlar, çevre, sosyoekonomik vs. özelliklerin etkisi tartışılmaktadır.

Çocukların işlediği suçlar, sosyal bir problem olduğu kadar çocuğun kendisine, ailesine ve çevreye verdiği zararlarla toplumun düzenini derinden etkileyen bir olgudur. Çocuklar, gelişimlerini henüz tam olarak tamamlamadıkları için çocukluk döneminde suç eyleminde bulunan bireyi suç işleyen değil, suça sürüklenen olarak ifade etmek daha doğru kabul edilmektedir (İçli, 2004). Nitekim Türkiye Cumhuriyeti kanunlarında suçlu çocuk tabiri yerine suça sürüklenen çocuk tabiri kullanılması manidardır.

Türkiye'de 'çocuk suçluluğu' olarak adlandırılan, bilimsel kaynaklarca 'Juvenile Delinquency' kavramıyla ifade edilen ve 'reşit olmayanın suçluluğu' anlamına gelen kavram çocukluk ve ergenlik döneminin büyük bir kısmını kapsamaktadır. Çocukların insani gelişim sürecinin erken aşamalarında olması sebebiyle, sosyal, bilişsel, bedensel gelişimleri bakımından özel bakım ve yardıma ihtiyaçları olduğu; özgürlük, güvenlik, barış ve değer koşullarında yasal korunmaya gereksinim duydukları göz önünde bulundurularak, Birleşmiş Milletler üye devletlerinin 29 Kasım 1985 tarihinde Pekin'de aldıkları kararlar neticesinde; çocuk suçluluğu; 'mevcut hukuk sistemi içinde ceza verilmesini gerektirecek her türlü eylem ve ihmaldir' şeklinde ifade edilmiştir (Beijing Kuralları m. 2, 1985). Türkiye Cumhuriyeti 'Çocuk Koruma Kanunu'nda suça sürüklenen çocuk; 'daha erken yaşta reşit olsa bile, 18 yaşını doldurmamış, kanunlarda suç olarak tanımlanan bir eylemi yaptığı iddiasıyla hakkında soruşturma yada kovuşturma yapılan veya yaptığı eylemden ötürü hakkında güvenlik tedbirlerine karar verilen çocuğu' ifade etmektedir. Çocuk Koruma Kanunu'nda; suç işleyen çocuğa suçlu demek yerine 'suça sürüklenen çocuk' ifadesi kullanılarak, çocuğun suç işlemesinin yetişkin birinin suç işlemesi gibi iradi bir davranış olmadığı, ancak aile, arkadaş, yaşadığı çevre şartları gibi birçok faktörün bir araya gelmesiyle suça sevk edildiği ve sonucunun çocuk tarafından düşünülmediği, zarar verme kastı olmayan duygusal bir davranış olarak görülmektedir ve bu sebeple suça sürüklenen çocuklar kanunlarca teminat altına alınmış ve yargılanma süreci yetişkinden ayrı kanunlarca, çocuk mahkemesinde ve çocuk hakimi tarafından yetişkinden farklı uygumalar ile yargılanmalarının yolu açılmıştır (Çocuk Koruma Kanunu, 2005; Uluğtekin, 2005).

Çağımızda çocuk suçluluğunun sebeplerinin çok faktörlü olduğu; çocukların içinde yaşadığı çevre, aile, arkadaş çevresi, eğitim, sosyal ve ekonomik politikalar, çalışma yaşamı 
gibi faktörlerin çocuğun yararına işlememesinin, çocuğun suça sürüklenmesine sebep teşkil ettiği konusunda görüş birliği bulunmaktadır. Çocuk suçluluğu sosyal bir uyumsuzluğun dişa yansımış hali, kişiyi toplum halinde yaşadığı bireylerin karşısına çıkaran bir olgudur (Uluğtekin, 2005; Akduman, Akduman, Cantürk, 2007).

Balcı (2011) çocuk suçluluğu ve toplumsal nedenlerini araştırdığı çalışmasında içinde bulunduğumuz çağın olumsuz etkileri, göç, düzensiz kentleşme, gecekondulaşma, medya gibi faktörlerin olumsuz etkileri çocuğun suça sürüklenmesine sebep olduğunu ifade etmektedir.

Hiç bir çocuk suçlu doğmaz ya da hiç bir çocuğun aklından suç işlemek geçmez. Çocukta suç davranışını anlayabilmek için kişisel, ailesel ve çevresel özelliklerinin bilinmesi gerekir. Bebeğin doğduğu andan itibaren, annesiyle veya onun bakımını sağlayan kişiyle kurduğu sevgi dolu, kararlı ve güvenli ilişkinin, duygusal bağın olmayışı, duygusal ve fiziksel istismara maruz kalması, ailenin çocuğu büyütürken kullandıkları olumsuz ebeveyn tutumları, aile ilişkilerinin azlığı, parçalanmış ailede büyüme, madde bağımlısı veya sabıkalı aile bireyleri, ailenin denetiminin ve desteğinin az olması, ihtiyaşlarının karşılanmaması gibi faktörlerin suç ile ilişkisi bulunmuştur (Akduman, Akduman, Cantürk, 2007). Bu açıdan çocukların algıladıkları anne baba tutumları ve ebeveyne bağlanma stillerinin çocuk suçluluğu ile ilişkisinin incelenmesi önem arz etmektedir.

Bowlby (1999) kişiliğin temellerinin atıldığı ilk beş y1llık erken çocukluk döneminde anneden ayrı kalmanın, çocukta suçlu kişilik yapısının gelişimine zemin hazırlayacağını ileri sürer. McCord (1991) çocuğun kişiliğinin oluştuğu dönemde en ağır sorumluluğun ailelerde olduğunu; çocuktaki uyumsuzluğu ortaya çıktığı dönemde önlememe ve uyumsuzluğa sebep olduğu gerekçesiyle ailenin sorumlu tutulması gerektiğini ileri sürmektedir. Demirli (2013) kaygılı bağlanmanın, annenin çocuk yetiştirme stili sevgi boyutu tarafından yordandığını; kaçınan bağlanmanın ise, baba çocuk yetiştirme stili kontrol- denetim boyutu tarafından zayıf bir şekilde yordandığını bulmuştur.

Bireyin her yönden gelişiminde, çevre koşullarının ve aile yaşantılarının büyük öneme sahip olduğu yapılan araştırmalarla ortaya konmaktadır. Sağlıklı çevrede, sağlıklı aile yaşantıları ve aile tutumları ile yetişen bireylerin her yönden sağlıklı geliştikleri, buna karşın sorunlu çevre, sorunlu aile yaşantıları ve aile tutumlarında yetişen bireylerin gelişimlerinde sorun ve aksaklıkların olduğu görülmektedir (Akın, 2009).

$\mathrm{Bu}$ araştırma çocuğu yetiştirmede sağlıklı tutumun hangisinin olduğunun belirlenmesi, suça sürüklenen çocukların algıladıkları anne-baba tutumlarının ve ebeveyne bağlanma stillerinin belirlenmesi ve bunlar arasında bir ilişkinin olup olmadığının bilinmesi ve çocuğun suça sürüklenmesinde ebeveyn tutumlarının ve ebeveyne bağlanma stillerinin etkisinin bilinmesi açısından önemlidir.

Yapılan araştırmalarda suçlu ailelerin çocuklarının suç işlediği görülmektedir. $\mathrm{Bu}$ çalışmalarda genetiğin ve yetiştirme faktörlerinin etkisi üzerinde durulmaktadır. Yapılan araştırmalarda kişiyi suç işlemeye yönelten bir genin varlığına rastlanmamıştır. Bu da çocuğu suça yöneltmede biyolojik etmenlerin ana neden olmadiğ 1 görüşünde araştırmacıları birleştirmiştir (Doğan, 1990). Çocuğun suça yönelmesinde bireysel etmenlerden ziyade çevresel etmenlerin daha etkili olduğu, birçok bireysel etmenin kaynağında çevresel etmenlerin bulunduğu kabul edilen bir gerçektir. Çocuğun hareketleri, davranışları içinde bulunduğu hayatın şartlarına göre şekil almaktadır. Bu sebeple çevresel etmenler olarak çocuğun içinde bulunduğu aile, okul iş ve arkadaş ortamı çocuk suçluluğu ile ilişkilidir (Sevük, 1998). Çocuğun suça yönelmelerinin yada yönelmemelerinin esas sebeplerini içinde bulunduğu aile ve çevre faktörlerinde aramak gerekmektedir. 
Çocuk doğduğu andan itibaren gelişimini bir aile içinde sürdürür. 'Evlilik ve kan bağına dayanan, karı, koca, çocuklar, kardeşler arasındaki ilişkilerin oluşturduğu toplum içindeki en küçük birlik aile' dir (Türk Dil Kurumu, 2011). Diğger bir deyişle aile; toplumun en küçük yapı taşı, en küçük sosyal grubudur. Her sosyal grubun nasıl kuralları varsa her ailenin de kendine özgü, aile içerisindeki bireylerin oluşturduğu kuralları vardır ve aileyi oluşturan bireyler bu kurallara uymak zorundadır. Bu kurallar sosyalleşmenin de ön koşuludur. Çocuk sosyalleşme süreci sırasında yaşam kurallarını ve bu kurallara uymayı, yolunda gitmeyen bazı durumlar karşısında nasıl baş edeceğini öğrenmektedir. Çocuğa toplumsal kuralları öğreten aile, çevresinde yaşanacak olumsuzluklar, zorlanmalar çocuğu istenmeyen davranışlara, suça yönelmelerine neden olabilmektedir (Ersin, 2010). Çocukların geçtikleri bu dönemde ebeveynin çocuğa karşı takındığı tutum ve davranışların çocukların suça yönelmelerinde etkili olduğu düşünülmektedir.

Çocuk yetiştirmede temel unsur fiziksel ihtiyaçlarının zamanında karşılanmasının yanı sıra sevgi ve eğitimdir. Sevgi ihtiyacının, hayatın her döneminde karşılanması gerekir. Çocuk her zaman her koşulda anne-babası tarafından sevildiğini bilmek ister. Çocuğu sevmek demek her istediğine evet demek, her istediğini yapmasına izin vermek, her davranışını onaylamak değildir. Davranışlarını düzene koymak adına bazı kurallar koymak, disipline etmek, eğitmek gerekir (Dirim, 2003, s. 26-28). Ailenin disiplin ve sevgideki yetersizliği ya da aşırılığı çocukta sağlıksız bir gelişime neden olur.

Ebeveynlerin çocuk yetiştirme yöntemlerinde kullandıkları tutumların birçoğu çocuk suçluluğuna sebep olmaktadır. Ebeveynin aşırı koruyucu-kollayıcı tavrı çocuğun özerkliğini kazanamayıp bağımlı bir kişilik gelişimine sebep olmaktadır. Yeterince sevgi göstermeyince yoksunluk dolayısıyla ciddi davranış problemleri oluşmaktadır. Sıkı disiplin çocuktan yaşının ve gelişiminin üstünde sorumluluk beklemeye ve cezaya başvurmaya sebep olmaktadır. Bu da çocuğun saldırganca davranmasına, kurallara başkaldırmasına sebep olur ve sıkı disiplim sonucunda da çocuğun suça sürüklenmesi kaçınılmaz bir hale gelir.

Işık (2003)'ın çocuk suçluluğunda ailenin etkilerinin incelendiği araştırmasında, çocuğun suça sürüklenmesinde aile yapısı, çocuğa sunulan imkanlar, verilen eğitim gibi değişkenlerin etkili olduğu sonucuna varılmıştır. Erdoğdu (2005) tarafından yapılan araştırmada, suça sürüklenen çocukların suça sürüklenmeyen çocuklara göre aile ilişkileri daha sağlıksız ve saldırganlık düzeyleri de daha yüksek bulunmuştur. Pardini, Loeber ve Stouthamer (2005)'in yaptığı çalışmada, aile ile ergen arasındaki çatışmada ergenin suçluluğa daha toleranslı bakmasına sebep olduğu bulunan diğer bir bulgudur. Sezer, Kolaç ve Erol (2013) tarafından yapılan araştırmada, anne ve babası otoriter olan öğrencilerin saldırganlık puanları, anne ve babası demokratik tutumla davranan öğrencilerden anlamlı derecede yüksek bulunmuştur. Tunceroğlu (2015) yaptığı çalışmada, dört ana etkenin çocukların yineleyen bir şekilde suç işlemesinde etkili olduğu saptanmıştır. Bunlar: Ailevi etkenler (ailede suçlu birinin olması, parçalanmış aile, ailede kişiler arasındaki ilişkilerin bozukluğu, şiddet, eğitim düzeyi düşük anne baba, çocuğun evden kaçmış olması, kalabalık ve geniş aile yapısı, düşük sosyoekonomik durum, ailede madde kullanımının varlığı, göç olgusu); çevresel etkenler (düşük soyokültürel çevrede büyüme, çevrenin suç işlemeye zemin hazırlaması, suç işleyenmadde bağımlısı akran grubu); bireysel etkenler (olumsuz kişisel özellikler, öğremin hayatını yarıda bırakma, düşük okul başarısı, madde kullanma); ve çocuğun suç hayatına ait etkenlerdir (erken yaşta suç işleme ve cezaevine girme, ilk işlenen suçun mala karşı işlenen suç olması, işlediği suçun fazlalığı).

Çocukların suça sürüklenmesinde, anne-baba tutumlarının etkisi var mıdır ve anne babanın çocuğu yetiştirme stilinin çocuğun benlik algısında ve yetişkine bağlanma tarzında ne derece etkisinin olduğu soruları gündeme gelir. Bu araştırmada; suça sürüklenen çocuklar ile 
suça sürüklenmeyen çocukların algıladıkları anne ve baba tutumları ile bağlanma stilleri arasında bir ilişki olup olmadığı araştırılması gereken bir problemdir.

$\mathrm{Bu}$ çalışmada suça sürüklenen çocuklar ile suça sürüklenmeyen çocukların anne ve babalarının nasıl bir tutum sergiledikleri, bunun bağlanmayla bir ilişkisinin olup olmadığı araştırılmıştır. Yapılan çalışmada aşağıda belirtilen altı araştırma sorusuna cevap aranmıştır;

1. Suça sürüklenen çocukların algıladıkları anne tutumlarına göre anneye bağlanma stili arasında anlamlı bir fark var midır?

2. Suça sürüklenen çocukların algıladıkları baba tutumlarına göre babaya bağlanma stili arasında anlamlı bir fark var midır?

3. Suça sürüklenen ve suça sürüklenmeyen çocukların algıladıkları anne tutumları arasında anlamlı bir farklılık var midır?

4. Suça sürüklenen ve suça sürüklenmeyen çocukların algıladıkları baba tutumları arasında anlamlı bir farklılık var midir?

5. Suça sürüklenen çocuklar ile suça sürüklenmeyen çocukların anneye bağlanma stili açısından aralarında anlamlı bir farklılık var midır?

6. Suça sürüklenen çocuklar ile suça sürüklenmeyen çocukların babaya bağlanma stili açısından aralarında anlamlı bir farklılık var mıdır?

\section{YÖNTEM}

Araştırma, suça sürüklenen çocuklar ile suça sürüklenmeyen çocukların algıladıkları anne ve baba tutumlarının karşılaştırılması ve bağlanma stillerinin incelenmesine yönelik ilişkisel tarama modeliyle yapılmış bir çalışmadır. Tarama modeli geçmişte ya da bulunulan zamanda var olan durumu var olduğu şekliyle tanımlayıp betimler. Araştırmaya konu olan durumu ve değișkenleri değiștirme ve etkileme çabası yoktur. $\mathrm{Bu}$ model yoluyla kısıtlı bir zaman diliminde çok geniş bir sahada bilgi toplanabildiği için seçilmiştir (Büyüköztürk, Akgün, Karadeniz, Demirel, K1lıç, 2014: 28).

Araştırmanın evrenini Diyarbakır ve Şanlıurfa illerinde bulunan suça sürüklenen çocuklar ve 2015-2016 eğitim öğretim yılında 9, 10, 11, 12. sınıflara devam eden ortaöğretim öğrencileri oluşturmaktadır. Araştırmanın örneklemini ise bu çocuklar içerisinden tesadüfi bir şekilde seçilen, evreni temsil eden 102 cezaevinde tutuklu- hükümlü bulunan ve denetimli serbestlik müdürlüğüne gelen suça sürüklenen çocuklardan, 108 ortaöğretim kurumunda öğrenim görmekte olan, toplam 210 çalışmaya gönüllü katılan çocuk oluşturmuştur. Araştırmada; örneklem sayısının belirlenmesinde basit seçkisiz örnekleme yöntemleri içerisinden ulaşılabilir örnekleme yolu kullanılmıştır. Basit seçkisiz örnekleme yönteminde; evreni oluşturan her birimin örneklem içinde yer alma olasılığı eşittir. Diğer bir ifadeyle tüm bireylerin seçilme olasılı̆̆ aynıdır ve bir bireyin seçimi diğer bireylerin seçimini etkilememektedir (Büyüköztürk vd., 2014, s. 85).

\subsection{Veri Toplama Araçları}

Veri toplama aracı olarak, Sümer ve Güngör (1999) tarafından geliştirilen 'Çocuk Yetiştirme Stilleri Ölçeği’; Günaydın, Selçuk, Sümer ve Uysal (2005) tarafindan geliştirilen 'Ebeveyn ve Arkadaşlara Bağlanma Envanteri (EABE)' kullanılmıştır.

\subsection{1. Çocuk Yetiştirme Stilleri Ölçeği}

Ölçek, ergen yetiştirme stillerini ölçmek için Maccoby ve Martin'in (1983) önerdiği boyutlar ile Lamborn ve arkadaşlarının (1991) çalışmaları örnek alınarak Sümer ve Güngör 
(1999) tarafından yeni maddeler eklenerek geliştirilmiştir. Ölçek 22 madde içermekte ve maddeler beşli derecelendirme üzerinden değerlendirilmektedir. Anne ve baba için ayrı ayrı değerlendirme imkanı bulunan ölçekte çocuk yetiştirme stillerinin altında yatan kabul/ilgi boyutunu ölçmek için 11 ve kontrol boyutunu ölçmek için 11 madde yer almaktadır. 1, 3, 4, 7, 9, 10, 14, 16. maddeler kabul/ilgi/sevgi boyutunu; 2, 5, 6, 8, 15, 17, 18, 19, 20, 21, 22. maddeler s1k1 denetim/kontrol boyutunu ölçmektedir. 11, 12 ve 13. maddeler ters yönde puanlanacak maddelerdir.

Kabul/ilgi boyutu anne-babanın çocuğu kabul etmesini, anlamasını ve çocuğuna gösterdiğgi sevgiyi ve ilgiyi değerlendirmektedir. Kontrol boyutu, ana-babanın çocuğun davranışlarını sınırlandırmasını, izlemesini ve çocukların disipline edilmesini içermektedir (Sümer ve Güngör, 1999). Her alt boyuttan alınan toplam puanın yüksekliği, o boyutun ifade ettiği tutumun yüksekliğini ortaya koymaktadır. Ölçek geliştirme çalışması ergenlerden, çocukluk dönemlerinde ana-babalarıyla olan ilişkilerini düşünerek geçmiş zamanda verilen ifadelere ne derecede katıldıklarını değerlendirmeleri istenmiştir (örneğin, 'her davranışımı s1k1 sıkıya kontrol etmek isterdi') (Sümer ve Güngör, 1999). Bu araştırmada, ifadeler geçmiş zamanda değil geniş zamanda verilmiştir (örneğin, 'her davranışımı sıkı sıkıya kontrol etmek ister). Ana-babalık sitillerinin zamana göre değişmez olması bu değişikliği getirmiştir. Çocuk Yetiştirme Stilleri Ölçeği'nden boyutlar ve kategorik olmak üzere iki düzeyde bilgi alınabilmektedir. Boyutlar temelinde kabul/ilgi ve kontrol; kategorik olarak ise her iki boyutta medyan değerin üstünde puan alanlar demokratik (demokratik), altında puan alanlar ise izin verici/ihmalkâr (ihmalkar) ana-babalar olarak sınıflandırılmaktadır. Kabul/ilgi boyutunda medyanın üstünde, kontrol boyutunda medyanın altında puan alanlar hoşgörülü (hoşgörülü); kabul/ilgi boyutunda medyanın altında, kontrol boyutunda medyanın üstünde puan alanlar ise otoriter ana-babalar olarak sınıflandırılmaktadır (Sümer ve Güngör, 1999).

Sümer ve Güngör (1999) çalışmada Çocuk Yetiştirme Stilleri Ölçeğinin iç tutarlılık sayılarını annenin gösterdiği kabul/ilgi ve kontrol boyutu için sırasıyla .81 ve .79; babanın gösterdiği kabul/ilgi ve kontrol boyutu için sırasıyla .91 ve .90 olarak bulmuştur. Ölçekte yer alan yönergede ölçeği yanıtlarken dikkat edilmesi gereken noktalar vurgulanmış ve öğrencilerden her madde için kendilerine en uygun seçeneği işaretlemeleri istenmiştir. Ölçeğin kullanımıyla ilgili araştırmacıdan izin alınmıştır.

\subsubsection{Ebeveyn ve Arkadaşlara Bağlanma Envanteri (EABE)}

Bu ölçek Armsden ve Greenberg' in (1987) hazırladığı 'Inventory of Parent and Peer Attachment” ölçeğinin Günaydın, Selçuk, Sümer ve Uysal (2005) tarafından Türkçe’ ye uyarlanmış halidir.

Orijinalinde 28 maddeden oluşan ölçeğin Raja ve arkadaşları (1992) tarafindan geliştirilen 12 maddelik kısa formunun standart çeviri-tekrar çeviri yöntemiyle Türkçe' ye çevrilmiş şekli kullanılmıştır. Ölçek, ergenlerin anne ve babalarına bağlanmalarını ölçmek amacıyla geliştirilmiş ve anneyle olan ilişkileri içeren 12 madde, babayla olan ilişkiler içeren 12 madde toplam 24 maddeden oluşmaktadır. Geçerlilik katsayısı anne formu için .88 olarak baba formu için .90 olarak saptanmış olup, güvenirlilik katsayısı anne formu için .87 olarak baba formu için .88 olarak test-tekrar test yöntemi kullanılarak bulunmuştur.

EABE kısa formu her biri dörder madde içeren 'Güven, İletişim, Yabancılaşma' alt ölçeklerinden oluşmaktadır. EABE, her madde 7 basamaklı ölçekler üzerinden değerlendirilmiştir ( 1 = asla, 7 daima) ve katılımcılar tarafından hem anne hem de baba için cevaplandırılmıştır. Böylelikle, 'Güven, İletişim ve ters kodlanan Yabancılaşma' alt ölçeklerinin toplanmasıyla toplam bağlanma puanı, anne-baba için ayrı ayrı hesaplanabilmektedir. Ölçekteki 1., 2., 3. ve 11. maddeler güveni; 6., 7., 8.ve 12. maddeler 
iletişimi; 4., 5., 9. ve 10. maddeler yabanc1laşmayı ölçmektedir. Envanterin güven, iletişim ve yabancılaşma alt boyutları ayrı ölçülebildiği gibi, güven boyutundan 2. madde, iletişim boyutundan 6. madde ve yabancılaşma boyutunun bütün maddeleri ters kodlanıp ve diğer maddelerle de toplandığında güvenli bağlanma puanına ulaşılmaktadır (Günaydın ve ark, 2005). Güven boyutu, ergenin güven duygusunu, bağlanma figürlerinin kendi duygusal durumlarında ihtiyaç, istek ve arzularına saygı göstermesini değerlendiriken; diğer boyutlar ergenlerin bağlanma figürlerine karşı öfke ve onlardan ayrışmayı değerlendirmektedir.

Ölçeğin üstünde yer alan yönergede cümlelerde anlatılan durum ne sıklıkta yaşanmışsa 7 aralıklı ölçekte, ilgili rakam üzerine (X) koyarak göstermeleri istenmiştir. Ölçekte yer alan yönergede ölçeği yanıtlarken dikkat edilmesi gereken noktalar vurgulanmış ve öğrencilerden her madde için kendilerine en uygun seçeneği işaretlemeleri istenmiştir. Ölçeğin kullanımıyla ilgili araştırmacıdan izin alınmıştır.

\section{BULGULAR VE TARTIŞMA}

$\mathrm{Bu}$ bölümde, araştırmanın temel problem ve alt sorularına yanıt bulmak için toplanan verilerin istatistiksel analizleri sonucunda elde edilen bulgular ve yorumlara yer verilmiştir.

Araştırma kapsamında örneklemi oluşturan katılımcılardan suça sürüklenen çocukların algıladıkları anne ve baba tutumları ile anne ve babaya bağlanma stili arasında anlamlı bir ilişkinin olup olmadığı; suça sürüklenen çocuklar ile suça sürüklenmeyen çocukların algıladıkları anne ve baba tutumları açısından aralarında anlamlı bir farklılığın bulunup bulunmadığı; suça sürüklenen çocuklar ile suça sürüklenmeyen çocukların anne ve babaya bağlanma stili açısından aralarında anlamlı bir farklılığın olup olmadığı sorularına yanıt vermek üzere, elde edilen verilerin istatistiksel analizleri sonucunda edinilen bulgular tablolarla gösterilmiştir.

Tablo 1'de suça sürüklenen çocukların algıladıkları anne tutumlarına göre anneye bağlanma stillerine ilişkin Kruskal Wallis Testi sonuçları görülmektedir.

Tablo 1. Suça Sürüklenen Çocukların Algıladıkları Anne Tutumlarına Göre Anneye Bağlanma Stillerine İlişkin Kruskal Wallis Testi Sonuçları

\begin{tabular}{|c|c|c|c|c|c|c|c|c|c|c|}
\hline & \multirow{2}{*}{ Anne Tutum } & \multirow{2}{*}{$\mathrm{n}$} & \multirow{2}{*}{ Ortalama } & \multirow{2}{*}{ Medyan } & \multirow{2}{*}{ Min. } & \multirow{2}{*}{ Mak. } & \multirow{2}{*}{ S.S. } & \multicolumn{3}{|c|}{ Kruskal Wallis } \\
\hline & & & & & & & & Sira Ort. & Test & $\mathrm{p}$ \\
\hline \multirow{4}{*}{ Anne Güven } & 1.Demokratik & 43 & 21,93 & 22,0 & 11,0 & 26,0 & 3,48 & 51,99 & \multirow{4}{*}{13,704} & \multirow{2}{*}{$0,003 *$} \\
\hline & 2.Hoşgörülü & 21 & 23,48 & 26,0 & 14,0 & 26,0 & 3,41 & 66,24 & & \\
\hline & 3.Otoriter & 21 & 21,33 & 23,0 & 10,0 & 26,0 & 4,92 & 52,33 & & \multirow{2}{*}{$2-4$} \\
\hline & 4.Ihmalkar & 17 & 17,12 & 19,0 & 2,0 & 26,0 & 7,34 & 31,03 & & \\
\hline \multirow{4}{*}{ Anne İletişim } & 1.Demokratik & 43 & 21,21 & 21,0 & 14,0 & 28,0 & 3,47 & 57,34 & \multirow{4}{*}{11,720} & \multirow{4}{*}{$\begin{array}{r}0,008 * \\
\text { Fark: } \\
4-1,2\end{array}$} \\
\hline & 2.Hoşgörülü & 21 & 20,86 & 20,0 & 10,0 & 28,0 & 5,69 & 55,26 & & \\
\hline & 3.Otoriter & 21 & 20,62 & 21,0 & 12,0 & 28,0 & 4,30 & 53,69 & & \\
\hline & 4.Ihmalkar & 17 & 16,92 & 19,0 & 6,0 & 26,0 & 5,03 & 29,38 & & \\
\hline \multirow{4}{*}{$\begin{array}{l}\text { Anne } \\
\text { Yabancılaşma }\end{array}$} & 1.Demokratik & 43 & 16,02 & 17,0 & 9,0 & 24,0 & 3,82 & 47,97 & \multirow{4}{*}{7,227} & \multirow{4}{*}{0,065} \\
\hline & 2.Hoşgörülü & 21 & 18,24 & 18,0 & 13,0 & 22,0 & 2,36 & 66,36 & & \\
\hline & a. Otoriter & 21 & 16,76 & 16,0 & 11,0 & 26,0 & 4,68 & 50,17 & & \\
\hline & 4.Ihmalkar & 17 & 15,41 & 16,0 & 4,0 & 21,0 & 4,60 & 43,74 & & \\
\hline
\end{tabular}

$*: \mathrm{p}<0,05$ 
Tablo 1'de uygulanan Kruskal Wallis analizi sonucunda anne tutumları grupları arasında anne güven, anne iletişim bakımından istatistiksel olarak anlamlı farklılık görülmektedir. Buna göre anne tutumu ihmalkar olan çocukların anne güven düzeyi anne tutumu hoşgörülü olan çocuklardan anlamlı derecede daha düşüktür. Anne tutumu otoriter olan çocukların anne güven düzeyi anne tutumu hoşgörülü olan çocuklardan anlamlı derecede daha düşüktür. Anne tutumu demokratik olan çocukların anne güven düzeyi $(21,93 \pm 3,48)$ iken hoşgörülü olanların $(23,48 \pm 3,41)$, otoriter olanların $(21,33 \pm 4,92)$ ve ihmalkar olanların ise $(17,12 \pm 7,34)$ dir.

Tablo 9'da görüldüğü gibi en yüksek güven puanları sırasıyla hoşgörülü ve demokratik davranan annelerin çocuklarında rastlanmaktadır. Annenin çocuğu hoşgörülü ve demokratik bir tutumla yaklaşmasının, çocuğun anneye güvenini arttırdığı söylenebilir. Bu sonucun çıkmasında çocuğu ihmal eden ve çocuğa otoriter davranan anneyle çocuğu arasında sağlıklı bağlanmanın kurulmamış olmasının neden olduğu söylenebilir.

Anne tutumu ihmalkar olan çocukların anne iletişim düzeyi anne tutumu demokratik ve hoşgörülü olan çocuklardan anlamlı derecede daha düşüktür. Anne tutumu demokratik olan çocukların anne iletişim düzeyi $(21,21 \pm 3,47)$ iken hoşgörülü olanların $(20,86 \pm 5,69)$, otoriter olanların $(20,62 \pm 4,30)$ ve ihmalkar olanların ise $(16,92 \pm 5,03)$ dir.

Anneyle kurulan iletişim puanının en yüksek olduğu anne tutumunun hoşgörülü tutum olduğu görülmektedir. Bu sonucun çıkmasında; annenin çocuğun her istediğine evet demesi, yaptığı yanlışlıkları hoşgörmesinin etkili olduğu, annenin hoşgörülü tutumun çocukla iletişimini arttırdığı sonucuna varılabilir. Annenin çocuğunu ihmal etmesinin ise çocukla iletişimini azalttığı görülmektedir.

Sümer ve Güngör (1999)'ün yaptığı araştırmada, anneden algılanan sıkı denetimkontrol boyutunun güvenli bağlanma ile olumsuz ilişki gösterdiği, korkulu ve saplantılı bağlanma ile olumlu ilişki gösterdiği saptanmıştır. Bu sonuç araştırma sonucuyla benzeşmektedir. Türktan (2004)'ın yaptığı çalışmada demokratik tutumlu annelere duyulan güvenin ve anneyle kurulan iletişimin fazla, baskıcı tutumlu annelere duyulan güvenin ve anneyle kurulan iletişimin az olduğu saptanmıştır. Yapılan araştırmanın sonucu ile bu sonuç benzeşmektedir. Tanış (2014) tarafından yapılan araştırmada, annenin davranış şekli ile güvenli-kayıtsız-korkulu-saplantılı bağlanma stilleri oranları arasında bir farklılık bulunmadığı saptanmıştır. Bu sonuç araştırma sonucuyla paralellik göstermemektedir. Bunun sebebi çalışılan grupların farklılıkları olabilir.

Tablo 2'de suça sürüklenen çocukların algıladıkları baba tutumlarına göre babaya bağlanma stillerine ilişkin Kruskal Wallis Testi sonuçları görülmektedir. 
Tablo 2. Suça Sürüklenen Çocukların Algıladıkları Baba Tutumlarına Göre Babaya Bağlanma Stillerine İlişkin Kruskal Wallis Testi Sonuçları

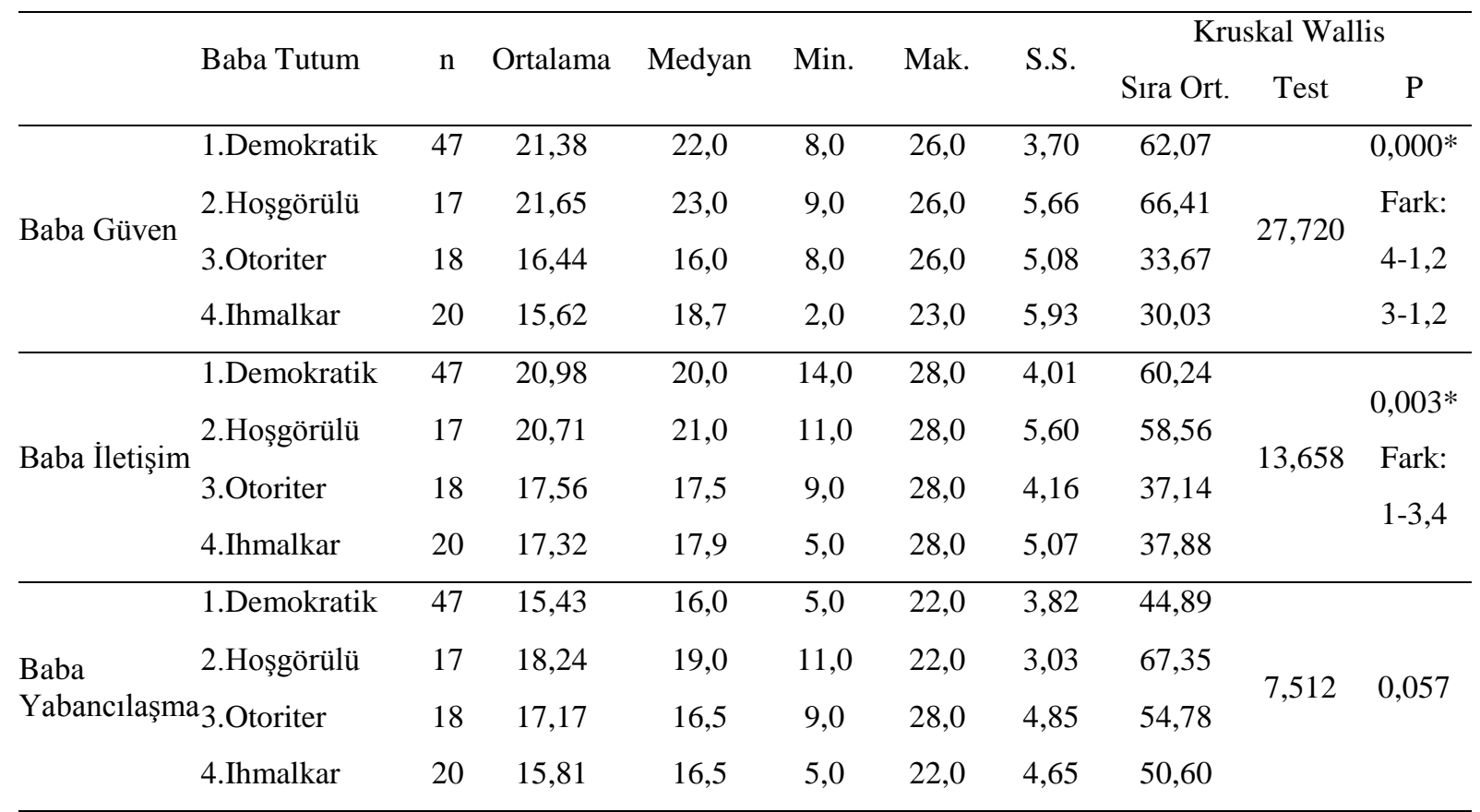

$*: \mathrm{p}<0,05$

Tablo 2 incelendiğinde; uygulanan Kruskal Wallis analizi sonucunda baba tutumları grupları arasında baba güven, baba iletişim bakımından istatistiksel olarak anlamlı farklılık bulunmaktadir.

Buna göre baba tutumu ihmalkar olan çocukların baba güven düzeyi baba tutumu demokratik ve hoşgörülü olan çocuklardan anlamlı derecede daha düşüktür. Baba tutumu otoriter olan çocukların baba güven düzeyi baba tutumu demokratik ve hoşgörülü olan çocuklardan anlamlı derecede daha düşüktür. Baba tutumu demokratik olan çocukların baba güven düzeyi $(21,38 \pm 3,70)$ iken hoşgörülü olanların $(21,65 \pm 5,66)$, otoriter olanların $(16,44 \pm 5,08)$ ve ihmalkar olanların ise $(15,62 \pm 5,93)$ dir.

Tablo 2'de görüldüğü gibi; baba tutumları ile güven puanları arasındaki ilişki anne tutumları ile güven arasındaki ilişkiyle benzerdir. En yüksek güven puanları sırasıyla hoşgörülü ve demokratik davranan babaların çocuklarında rastlanmaktadır. Babanın çocuğu hoşgörülü, demokratik bir tutumla yaklaşmasının, çocuğun babaya güvenini arttırdığ 1 söylenebilir. Bu sonucun çıkmasında çocuğu ihmal eden ve çocuğa otoriter davranan babayla çocuğu arasında sağlıklı bağlanmanın kurulmamış olmasının neden olduğu söylenebilir.

Baba tutumu ihmalkar olan çocukların baba iletişim düzeyi baba tutumu demokratik ve hoşgörülü olan çocuklardan anlamlı derecede daha düşüktür. Baba tutumu demokratik olan çocukların baba iletişim düzeyi $(20,98 \pm 4,01)$ iken hoşgörülü olanların $(20,71 \pm 5,6)$, otoriter olanların $(17,56 \pm 4,16)$ ve ihmalkar olanların ise $(17,32 \pm 5,07)$ dir.

Babayla kurulan iletişim puanının en yüksek olduğu baba tutumlarının sırasıyla; demokratik ve hoşgörülü tutumlar olduğu görülmektedir. Bu sonucun çıkmasında; babanın çocuğa güven verip desteklemesinin ve çocuğun her istediğine evet demesi, yaptığ1 yanlışlıkları hoşgörmesinin etkili olduğu, babanın demokratik ve hoşgörülü tutumun çocukla iletişimini arttırdığı sonucuna varılabilir. Anne tutumlarında olduğu gibi, babanın da çocuğunu ihmal etmesinin çocukla iletişimini azalttığı görülmektedir. 
Sümer ve Güngör (1999)'ün yaptı̆̆ı araştırmada, sadece babadan algılanan sık1 denetim- kontrol boyutunun güvenli bağlanma ile anlamlı ilişki göstermediği saptanmıştır. Aynı araştırmada hem anne hem de babadan algılanan kabul- ilgi boyutunun güvenli bağlanma ile olumlu yönde ve anlamlı ilişki gösterdiği, güvensiz bağlanma türleri ile olumsuz yönde ve çoğunlukla anlamlı ilişki gösterdiği saptanmıştır sonucu araştırma sonucu ile paralellik göstermektedir. Türktan (2004)'ın yaptı̆̆ ç̧alışmada demokratik tutumlu babalara duyulan güvenin ve babayla kurulan iletişimin fazla, baskıcı tutumlu babalara duyulan güvenin ve babayla kurulan iletişimin az olduğu saptanmıştır. Yapılan araştırmanın sonucu ile bu sonuç benzerlik göstermektedir. Algan ve Şendil (2013)'in yaptığı araştırmada demokratik tutuma sahip ebeveylerin çocuklarının yüksek bağlanma puanına sahip olduklarını, izin verici ve aşırı koruyucu tutumlara sahip ebeveynlerin çocuklarının ise düşük puana sahip olduklarını saptamıştır. Bu sonuç araştırma bulgularıyle benzerlik göstermektedir. Tanış (2014)'ın yaptığı araştırmada babanın davranış şekli ile güvenli-kayıtsız-korkulu-saplantılı bağlanma stilleri oranları arasında bir farklılık bulunmadığını tespit edilmiştir. Bu sonuç araştırma sonucu ile benzeşmemektedir.

Araştırma bulgularına göre ebeveynlerin çocuğunu ihmal etmesinin ve çocuğa karş1 ilgisiz davranmasının, anne baba ile çocuk arasındaki iletişimin azalmasına sebep olmakta ve çocuğun ebeveynine güvensiz ve saplantılı bağlanmasına sebep olmaktadır. Güvensiz ve saplantılı bağlanmanın çocuğun psikolojik durumu üzerinde de yarattığı olumsuz etki düşünülünce, çocuk ebeveynin ilgisini ve sevgisini kaybettiği için acı çeker ve kendini güvende hissetmez. Bu sebeple saldırganca davranmaya başlar, sorunlu davranmaya başlar. Problemli davranışlar ve saldırganlık sonucu kaçınılmaz son suç işlemektir.

Tablo 1 ve Tablo 2'de suça sürüklenmiş çocukların anne ve baba tutumların bağlanma ile ilişkisiyle ilgili elde edilen bilgiler genel olarak alan yazın taraması sonucu elde edilen bilgilerle tutarlidir.

Tablo 3'te suça sürüklenen çocuklar ile suça sürüklenmeyen çocukların algıladıkları anne tutumlarına ilişkin Ki Kare testi sonuçları görülmektedir.

Tablo 3. Suça Sürüklenen Çocuklar İle Suça Sürüklenmeyen Çocukların Algıladıkları Anne Tutumlarına İlişkin Ki Kare Testi Sonuçları

\begin{tabular}{|c|c|c|c|c|c|c|c|c|c|}
\hline & \multicolumn{9}{|c|}{ Anne Tutumu } \\
\hline & & & $\begin{array}{l}\text { Demokra- } \\
\text { tik }\end{array}$ & Hogörülü & Otoriter & İhmalkar & Toplam & $\begin{array}{c}\mathrm{Ki} \\
\text { Kare }\end{array}$ & $\mathrm{p}$ \\
\hline \multirow{4}{*}{ Grup } & Suça & Say1 & 43 & 21 & 21 & 17 & 102 & \multirow{4}{*}{17,222} & \multirow{4}{*}{$0,001 *$} \\
\hline & Sürüklenmiş & Yüzde & 63,2 & 58,3 & 45,7 & 28,3 & 48,6 & & \\
\hline & \multirow{2}{*}{$\begin{array}{l}\text { Suça } \\
\text { Sürüklenmemiş }\end{array}$} & Sayı & 25 & 15 & 25 & 43 & 108 & & \\
\hline & & Yüzde & 36,8 & 41,7 & 54,3 & 71,7 & 51,4 & & \\
\hline \multirow{2}{*}{ Toplan } & & Say1 & 68 & 36 & 46 & 60 & 210 & & \\
\hline & & Yüzde & 100,0 & 100,0 & 100,0 & 100,0 & 100,0 & & \\
\hline
\end{tabular}

Tablo 3 incelendiğinde uygulanan ki kare analizi sonucunda suça sürüklenen çocuklar ve suça sürüklenmeyen çocukların anne tutumları arasında istatistiksel olarak anlamlı ilişki bulunmaktadir.

Buna göre anne tutumu demokratik ve hoşgörülü olan çocuklarda suça sürüklenenlerin oranı anne tutumu ihmalkar olanlardan anlamlı derecede daha fazladır. Anne tutumu demokratik olanlarda suça sürüklenenlerin oranı $\% 63,2$ iken hoşgörülülerde $\% 58,3$, otoriterlerde $\% 45,7$ ve ihmalkarlarda ise $\% 28,3$ 'tür. 
Tablo 4'da suça sürüklenen çocuklar ile suça sürüklenmeyen çocukların algıladıkları baba tutumlarına ilişkin Ki Kare testi sonuçları görülmektedir.

Tablo 4. Suça Sürüklenen Çocuklar İle Suça Sürüklenmeyen Çocukların Algıladıkları Baba Tutumlarına İlişkin Ki Kare Testi Sonuçları

\begin{tabular}{|c|c|c|c|c|c|c|c|c|c|}
\hline & \multicolumn{9}{|c|}{ Baba Tutumu } \\
\hline & & & $\begin{array}{l}\text { Demokra- } \\
\text { tik }\end{array}$ & $\begin{array}{l}\text { Hoşgörü- } \\
\text { lü }\end{array}$ & Otoriter & İhmalkar & Toplam & $\begin{array}{c}\mathrm{Ki} \\
\text { Kare }\end{array}$ & $\mathrm{p}$ \\
\hline \multirow{4}{*}{ Grup } & Suça & Say1 & 47 & 17 & 18 & 20 & 102 & \multirow{4}{*}{21,016} & \multirow{4}{*}{$0,000 *$} \\
\hline & Sürüklenmiş & Yüzde & 69,1 & 45,9 & 47,4 & 30,3 & 48,6 & & \\
\hline & \multirow{2}{*}{$\begin{array}{l}\text { Suça } \\
\text { Sürüklenmemiş }\end{array}$} & Say1 & 21 & 20 & 20 & 47 & 108 & & \\
\hline & & Yüzde & 30,9 & 54,1 & 52,6 & 70,1 & 51,4 & & \\
\hline \multirow{2}{*}{ Toplam } & & Say1 & 68 & 37 & 38 & 67 & 210 & & \\
\hline & & Yüzde & 100,0 & 100,0 & 100,0 & 100,0 & 100,0 & & \\
\hline
\end{tabular}

$*: \mathrm{p}<0,05$

Tablo 4 incelendiğinde uygulanan ki kare analizi sonucunda suça sürüklenen çocuklar ve suça sürüklenmeyen çocukların baba tutumları arasında istatistiksel olarak anlamlı ilişki bulunmaktadir.

Buna göre baba tutumu demokratik olan çocuklarda suça sürüklenenlerin oranı baba tutumu ihmalkar olanlardan anlamlı derecede daha fazladır. Baba tutumu demokratik olanlarda suça bulaşanların oranı $\% 69,1$ iken hoşgörülülerde $\% 45,9$, otoriterlerde $\% 47,4$ ve ihmalkarlarda ise \%30,3'tür.

Tablo 3 ve Tablo 4'teki sonuçlar her ne kadar beklenilen sonuç olmamakta ise de genel olarak anne babanın demokratik olmasının çocuğun suça yönelmesini engellediği görüşü desteklenebilir. Literatür incelendiğinde yapılan araştırmaların bu görüşü desteklediği görülmektedir. Anne babaların çocuklarına karşı gerektiği durumlarda kabul- ilgi ve kontroldenetleme tutumlarını sergilemeleri, çocuklarının suça yönelmelerini azalttığı söylenebilir.

Nitekim Haapasalo ve Pokelo (1999)'un yaptığı araştırmada bu savı destekler bulgulara ulaşılmıştır. Araştırmada olumsuz ebeveyn tutumlarına (cezalandırıcı, otoriter, izin verici, ihmalkar, vs.) maruz kalan çocukların yaşamlarının ilerleyen yıllarında saldırgan ve suç işlemeye meyilli oldukları belirlenmiştir. Ersin (2010) yaptığı araştırmada da olumsuz ebeveyn tutumlarının çocuklarda görülen davranış problemlerini arttırdığı yönünde bulgulara ulaşılmıştır. Ebeveyn tutumlarında kabul- ilgi arttıkça okul kurallarını bozma davranışı, statü suçu davranış1, tahrip suçu davranışı, fiziksel saldırganlık suçu davranışı, çalma suçu davranışının azaldığı saptanmıştır. Ebeveyn tutumlarında kontrol- denetleme arttıkça okul kurallarını bozma davranışı, statü suçu davranışı, tahrip suçu davranışı, fiziksel saldırganlık suçu davranışı, çalma suçu davranışının azaldığı saptanmıştır. Sezer, Kolaç ve Erol (2013)'un yaptığı araştırmada otoriter ebeveyne sahip ilköğretim çağında okuyan 4,5 ve 6 . sınıf öğrencilerinin demokratik ebeveyne sahip ilköğretim çağında okuyan 4,5 ve 6 . sınıf öğrencilerine göre daha saldırgan oldukları gözlenmiştir. Bolattekin (2014)'in yaptığı araştırmada demokratik tutuma sahip ebeveyn ile çocuklarında duygusal problemler ve akran sorunları görülmesi arasında negatif yönlü anlamlı bir ilişki olduğunu saptanmıştır, ayrıca ebeveynin demokratik tutuma sahip olması çocuğun sosyal davranışlar göstermesini artırmaktadır. Bu sonuca göre ebeveynin çocuğuna demokratik davranmasının çocuklarda olası duygusal sorunları engellediği, bu sayede suça sürüklenmesine engel olduğu; ayrıca 
demokratik tutumlu ebeveynlerin çocuklarının arkadaşlarıyla daha iyi geçinmesine ve daha sosyal olmasına vesile olduğu görülmektedir.

Yukarda belirtilen araştırma sonuçları ve benzer araştırmaların sonuçları, yapılan araştırma sonucu ile benzeşmemektedir. Yapılan araştırmada çıkan sonucun, alan yazın taramasında elde edilen sonuçlarla farklılaşmasının sebebi; suça sürüklenen çocuklarının bulundukları konum itibariyle ebeveyn davranışlarını algılamadaki sorunlardan kaynaklı olduğu düşünülmektedir. Suça sürüklenmeden önce ebeveynleri tarafından sunulan sinırsız özgürlük ortamını, yanlış davranışların da sunulan bu özgürlük alanı içerisinde hoşgörülmesini, düzeltilmesi gerekli hatalara müdahele edilmemesi gibi olumsuz ebeveyn tutumlarını, demokratik ebeveyn tutumu olarak algıladıkları düşünülmektedir. Aynı zamanda yaptıkları eylemin toplum tarafından kabul görmeyip cezalandırılmaları sebebiyle cezaevinde bulunan ve cezaevindeki zor koşullarda yaşamak durumunda kalan çocukların algılarının sağlıklı olmayacağı düşünülmektedir.

Yaptığ 1 bir hata yüzünden ebeveyninden dayak yiyen bir çocuğun yediği dayaktan sonra kendini kötü ebeveynini iyi olarak görmesi gibi; suça sürüklenen çocukların da işledikleri suçtan dolayı ceza almaları sebebiyle kendilerini kötü, ebeveynlerini iyi algılama eğilimi içinde oldukları, ebevyne karşı kendilerini mahçup hisssetmekte ve sorunlu kişi olarak kendilerini görmekte oldukları düşünülmektedir.

Tablo 5'te suça sürüklenen çocuklar ile suça sürüklenmeyen çocukların anneye bağlanma stillerine ilişkin Mann Whitney U testi sonuçları görülmektedir.

Tablo 5. Suça Sürüklenen Çocuklar İle Suça Sürüklenmeyen Çocukların Anneye Bağlanma Stillerine İlişkin Mann Whitney U Testi Sonuçları

\begin{tabular}{|c|c|c|c|c|c|c|c|c|c|c|}
\hline & \multirow{2}{*}{ Grup } & \multirow[b]{2}{*}{$\mathrm{n}$} & \multirow[b]{2}{*}{ Ortalama } & \multirow[b]{2}{*}{ Medyan } & \multirow[b]{2}{*}{ Min. } & \multirow[b]{2}{*}{ Mak. } & \multirow[b]{2}{*}{ S.S. } & \multicolumn{3}{|c|}{ Mann Whitney U Testi } \\
\hline & & & & & & & & Sira Ort. & $\mathbf{Z}$ & $\mathbf{p}$ \\
\hline \multirow{2}{*}{ Anne Güven } & Suça Sürüklenen & 102 & 21,32 & 22,0 & 2,0 & 26,0 & 4,98 & & \multirow{2}{*}{$-4,482$} & \multirow{2}{*}{$0,000 *$} \\
\hline & Sürüklenmeyen & 108 & 18,16 & 18,5 & 5,0 & 26,0 & 5,51 & 87,34 & & \\
\hline \multirow{2}{*}{ Anne İletişim } & Suça Sürüklenen & 102 & 20,30 & 20,0 & 6,0 & 28,0 & 4,63 & 110,95 & \multirow{2}{*}{$-1,266$} & \multirow{2}{*}{0,205} \\
\hline & Sürüklenmeyen & 108 & 19,05 & 20,0 & 6,0 & 28,0 & 5,84 & 100,35 & & \\
\hline \multirow{2}{*}{$\begin{array}{l}\text { Anne } \\
\text { Yabancılaşma }\end{array}$} & Suça Sürüklenen & 102 & 16,53 & 17,0 & 4,0 & 26,0 & 3,97 & 113,32 & \multirow{2}{*}{$-1,824$} & \multirow{2}{*}{0,068} \\
\hline & âürüklenmeyen & 108 & 15,49 & 16,0 & 3,0 & 23,0 & 3,86 & 98,11 & & \\
\hline
\end{tabular}

$*: p<0,05$

Tablo 5 incelendiğinde uygulanan Mann Whitney $U$ testi sonucunda suça sürüklenen ve sürüklenmeyen çocuklar arasında anne güven bakımından istatistiksel olarak anlamlı farklılık bulunmaktadır

Buna göre suça sürüklenen çocukların anne güven düzeyleri, suça sürüklenmeyen çocuklardan anlamlı derecede daha yüksektir. Suça sürüklenmiş çocukların anne güven düzeyi $(21,32 \pm 4,98)$ iken suça suça sürüklenmemiş çocukların ise $(18,16 \pm 5,51)$ dir. Gruplara ait puan ortalamalarına bakıldığında benzer düzeyde olmadığı görülmektedir

$\mathrm{Bu}$ sonuca varılmasında; annenin çocuğun yanlışlarını kapatacığının, çocuğun yaptığ herşeyin anne tarafından hoşgörüleceğinin, her zaman ve her koşulda annesinin onu destekleyeceğinin çocuk tarafından bilinmesi sebebiyle, çocukta anneye karşı bir güven oluşmaktadır. Oluşan bu güven duygusunun da, çok rahat bir şekilde çocuğun suça yönelmesine sebep teşkil ettiği düşünülmektedir. 
Balcı (2011)'nın yaptı̆̆ı araştırmada madde kullanan ergenlerde çocukluk çağı tramvası olanların anne ve babayla güven ilişkisi ve iletişimininin az, yabancılaşmasının ise fazla olduğu saptanmıştır. Bu sonuç araştırma sonucu ile benzeşmemektedir. Sonuçlar arasındaki farklılığın sebebi çalışılan gruplar arasındaki farklılıktan kaynaklandığ düşünülmektedir.

Tablo 6'da suça sürüklenen çocuklar ile suça sürüklenmeyen çocukların babaya bağlanma stillerine ilişkin Mann Whitney U testi sonuçları görülmektedir.

Tablo 6. Suça Sürüklenen Çocuklar İle Suça Sürüklenmeyen Çocukların Babaya Bağlanma Stillerine İlişkin Mann Whitney U Testi Sonuçları

\begin{tabular}{|c|c|c|c|c|c|c|c|c|c|c|}
\hline & \multirow{2}{*}{ Grup } & \multirow{2}{*}{$\mathrm{n}$} & \multirow{2}{*}{ Ortalama } & \multirow{2}{*}{ Medyan } & \multirow{2}{*}{ Min. } & \multirow{2}{*}{ Mak. } & \multirow{2}{*}{ S.S. } & \multicolumn{3}{|c|}{ Mann Whitney U Testi } \\
\hline & & & & & & & & Sura Ort. & $\mathbf{Z}$ & $\mathbf{p}$ \\
\hline \multirow{2}{*}{ Baba Güven } & Suça Sürüklenen & 102 & 19,43 & 20,0 & 2,0 & 26,0 & 5,41 & 113,47 & \multirow{2}{*}{$-1,854$} & \multirow{2}{*}{0,064} \\
\hline & Sürüklenmeyen & 108 & 18,01 & 19,0 & 5,0 & 28,0 & 5,75 & 97,97 & & \\
\hline \multirow{2}{*}{ Baba İletişim } & Suça Sürüklenen & 102 & 19,61 & 20,0 & 5,0 & 28,0 & 4,78 & 124,52 & \multirow{2}{*}{$-4,417$} & \multirow{2}{*}{$0,000 *$} \\
\hline & Sürüklenmeyen & 108 & 16,29 & 16,0 & 5,0 & 28,0 & 6,01 & 87,54 & & \\
\hline \multirow{2}{*}{$\begin{array}{l}\text { Baba } \\
\text { Yabancılaşm }\end{array}$} & Suça Sürüklenen & 102 & 16,28 & 16,5 & 5,0 & 28,0 & 4,16 & 102,22 & \multirow{2}{*}{$-0,764$} & \multirow{2}{*}{0,445} \\
\hline & aSürüklenmeyen & 108 & 16,80 & 17,0 & 8,0 & 28,0 & 4,39 & 108,60 & & \\
\hline
\end{tabular}

$*: \mathrm{p}<0,05$

Tablo 6 incelendiğinde uygulanan Mann Whitney U testi sonucunda suça sürüklenen ve sürüklenmeyen çocuklar arasında baba iletişim bakımından istatistiksel olarak anlamlı farklılık bulunmaktadır.

Buna göre suça sürüklenen çocukların baba iletişim düzeyleri suça sürüklenmeyen çocuklardan anlamlı derecede daha fazladır. Suça sürüklenmiş çocukların baba iletişim düzeyi $(19,61 \pm 4,78)$ iken suça sürüklenmemiş çocukların ise $(16,29 \pm 6,01)$ dir.Gruplara ait puan ortalamalarına bakıldığında benzer düzeyde olmadığı görülmektedir.

Yapılan çalışmada baba ile iletişim arttıkça suça sürüklenme de arttıyor görülmektedir. $\mathrm{Bu}$ sonucun çıkmasında; ebeveyn tutumlarındaki sağlıksız algılama benzeri bir bozukluğun, babayla kurulan iletişimin algılanmasında da yaşanıldığı düşünülmektedir.

Nitekim Balcı (2011)'nın yaptığı madde kullanım bozukluğu olan ergenlerde çocukluk çağı travmalarının bağlanma ile ilişkisini incelediği araştırmasında, yaşları 16 ile 18 arasında değişen 110 madde kullanım bozukluğu tanısı almış ergen hastayla yapılan görüşme ve anketler sonucunda çocukluk çağı travması ile babayla iletişim ve yabancılaşma alt boyutu arasında istatistiksel olarak ileri derecede anlamlı bir ilişki bulunmaktadır. Travmalı çocukların, güvensiz bağlanma ve saplantılı bağlanma puanları travması olmayan çocuklara göre daha yüksek çıkarken; travması olmayan çocukların güvenli bağlanma puanları travması olan çocuklara göre daha yüksek bulunmuştur. $\mathrm{Bu}$ araştırma sonucu göstermektedir ki bebeklik çağında ebeveynle kurulan sağlıksız ve güvene dayalı olmayan ilişkinin ve iletişimin çocukta başta madde kullanımı olmak üzere bir çok suça yönelmesine ve çocukta travmaya neden olmaktadır. Aynı şekilde Kesebir, Kavzoğlu ve Üstündağ (2011)'ın yaptığı araştırmada güvensiz bağlanma ile anksiyete bozuklukları, depresif bozukluklar, kaçıngan bağlanma davranış bozukluğu ve diğer dışa vuruk patolojilerle arasında ilişki olduğunu saptanmıştır. Psikopatolojik durumların çocuğun suça sürüklenmesinde bir etken olduğu düşünülünce, ebeveyne güvensiz bağlanmanın çocuğu suça yönelmesinde etkili olduğu söylenebilir.

Literatür incelendiğinde çocukların anne ve babasıyla kurduğu güven ve iletişim düzeylerinin fazla olmasının çocuğun suça sürüklenmesine engel olduğu sonucuna varılabilir. 
Çocuk anne ve babaya güvenli bağlandıkça, iletişimi arttıkça suçtan uzaklaşmaktadır; anne babaya yabancılaştıkça ise suça sürüklenme ihtimali artmaktadır. Her ne kadar tüm araştırmalarda, suç ile güvensiz ve saplantılı bağlanmanın ilişkili olduğunun ön planda olduğu bildirilmişse de, çalışma grubu farklılıklarından ya da bağlanma tarzının sağlıklı algılanmayışından kaynaklı özellikler nedeniyle yapılan çalışmada alan yazın taramasından farklı sonuçlara ulaşılmıştır.

\section{SONUÇ VE ÖNERILER}

$\mathrm{Bu}$ araştırma, suça sürüklenen çocuklar ile suça sürüklenmeyen çocukların algıladıkları anne ve baba tutumları ile ebeveyne bağlanma stillerini incelemek ve karşılaştırmak amacıyla yapılmıştır. Araştırmanın çalışma grubunu; 03.08.2015 ve 20.12.2015 tarihleri arasında Diyarbakır ve Şanlıurfa illerinde bulunan, cezaevinde tutuklu- hükümlü bulunan ve denetimli serbestlik müdürlügüne gelen 102 suça sürüklenen çocuk ile 9., 10., 11., 12. siniflara devam eden 108 ortaöğretim öğrencisi, toplam 210 çocuk oluşturmuştur. Araştırmada; örneklem sayısının belirlenmesinde basit seçkisiz örnekleme yöntemleri içerisinden ulaşılabilir örnekleme yolu kullanılmıştır. Araştırmada veri toplama aracı ile çocuklara sırasıyla 'Çocuk Yetiştirme Stilleri' ve 'Ebeveyn ve Arkadaşlara Bağlanma' ölçekleri uygulanmıştır.

Tablo 1'de suça sürüklenen çocularda algılanan anne tutumları grupları arasında bağlanma stilinin alt boyutlarından anne güven, anne iletişim bakımından istatistiksel olarak anlamlı farklılık görülmektedir.

Anne tutumu ihmalkar olan çocukların anne güven düzeyi, anne tutumu demokratik ve hoşgörülü olan çocuklardan anlamlı derecede daha düşüktür. Anne tutumu otoriter olan çocukların anne güven düzeyi, anne tutumu hoşgörülü olan çocuklardan anlamlı derecede daha düşüktür. Anne tutumu demokratik olan çocukların anne güven düzeyi $(21,93 \pm 3,48)$ iken hoşgörülü olanların $(23,48 \pm 3,41)$, otoriter olanların $(21,33 \pm 4,92)$ ve ihmalkar olanların ise $(17,12 \pm 7,34)$ dir.

Anne tutumu ihmalkar olan çocukların anne iletişim düzeyi anne tutumu demokratik ve hoşgörülü olan çocuklardan anlamlı derecede daha düşüktür. Anne tutumu demokratik olan çocukların anne iletişim düzeyi $(21,21 \pm 3,47)$ iken hoşgörülü olanların $(20,86 \pm 5,69)$, otoriter olanların $(20,62 \pm 4,30)$ ve ihmalkar olanların ise $(16,92 \pm 5,03)$ dir.

Tablo 2'de suça sürüklenen çocuklarda algılanan baba tutumları grupları arasında bağlanma stilinin alt boyutlarından olan baba güven, baba iletişim bakımından istatistiksel olarak anlamlı farklılık bulunmaktadır.

Buna göre baba tutumu ihmalkar olan çocukların baba güven düzeyi baba tutumu demokratik ve hoşgörülü olan çocuklardan anlamlı derecede daha düşüktür. Baba tutumu otoriter olan çocukların baba güven düzeyi baba tutumu demokratik ve hoşgörülü olan çocuklardan anlamlı derecede daha düşüktür. Baba tutumu demokratik olan çocukların baba güven düzeyi $(21,38 \pm 3,70)$ iken hoşgörülü olanların $(21,65 \pm 5,66)$, otoriter olanların $(16,44 \pm 5,08)$ ve ihmalkar olanların ise $(15,62 \pm 5,93)$ dir.

Baba tutumu ihmalkar olan çocukların baba iletişim düzeyi baba tutumu demokratik ve hoşgörülü olan çocuklardan anlamlı derecede daha düşüktür. Baba tutumu demokratik olan çocukların baba iletişim düzeyi $(20,98 \pm 4,01)$ iken hoşgörülü olanların $(20,71 \pm 5,6)$, otoriter olanların $(17,56 \pm 4,16)$ ve ihmalkar olanların ise $(17,32 \pm 5,07)$ dir.

Tablo 3'de suça sürüklenen çocuklar ve suça sürüklenmeyen çocukların algıladıkları anne tutumları arasında istatistiksel olarak anlamlı ilişki bulunmaktadır. 
Buna göre anne tutumu demokratik ve hoşgörülü olan çocuklarda suça sürüklenenlerin oranı anne tutumu ihmalkar olanlardan anlamlı derecede daha fazladır. Anne tutumu demokratik olanlarda suça bulaşanların oranı $\% 63,2$ iken hoşgörülülerde $\% 58,3$, otoriterlerde $\% 45,7$ ve ihmalkarlarda ise $\% 28,3$ 'tür.

Tablo 4'de suça sürüklenen çocuklar ve suça sürüklenmeyen çocukların algıladıkları baba tutumları arasında istatistiksel olarak anlamlı ilişki bulunmaktadır.

Buna göre baba tutumu demokratik olan çocuklarda suça sürüklenenlerin oranı baba tutumu ihmalkar olanlardan anlamlı derecede daha fazladır. Baba tutumu demokratik olanlarda suça bulaşanların oranı $\% 69,1$ iken hoşgörülülerde $\% 45,9$, otoriterlerde $\% 47,4$ ve ihmalkarlarda ise \%30,3'tür.

Tablo 5'de suça sürüklenen çocuklar ve sürüklenmeyen çocuklar arasında bağlanma stilinin alt boyutlarından anne güven bakımından istatistiksel olarak anlamlı farklılık bulunmaktadir.

Buna göre suça sürüklenen çocukların anne güven düzeyleri suça sürüklenmeyen çocuklardan anlamlı derecede daha fazladır. Suça sürüklenmiş çocukların anne güven düzeyi $(21,32 \pm 4,98)$ iken suça suça sürüklenmemiş çocukların ise $(18,16 \pm 5,51)$ dir Gruplara ait puan ortalamalarına bakıldığında benzer düzeyde olmadığı görülmektedir.

Tablo 6' da suça sürüklenen çocuklar ve sürüklenmeyen çocuklar arasında bağlanma stilinin alt boyutlarından baba iletişim bakımından istatistiksel olarak anlamlı farklılık bulunmaktadır.

Buna göre suça sürüklenen çocukların baba iletişim düzeyleri suça sürüklenmeyen çocuklardan anlamlı derecede daha fazladır. Suça sürüklenmiş çocukların baba iletişim düzeyi $(19,61 \pm 4,78)$ iken suça suça sürüklenmemiş çocukların ise $(16,29 \pm 6,01)$ dir. Gruplara ait puan ortalamalarına bakıldığında benzer düzeyde olmadığı görülmektedir.

Anne baba tutumlarıyla ve bebeklik döneminde kurulucak güvenli bağlanma ile ilgili ebeveynleri bilgilendirmeye yönelik aile eğitimleri düzenlenmelidir.

Çocukların ebeveynlerine güvenli bağlanmaya sahip olmaları için aile içerisinde ebeveynlerle ve diğer bireylerle sağlıklı bir ilişkinin kurulması sağlanmalı, ebeveynler çocuklarına karşı daha duyarlı, çocuklarının duygu ve düşüncelerini paylaşan, demokratik, güven verici ve eşitlikçi bir tutum sergilemelilerdir.

Çocuk suçluluğunu önlemek ve kontrol altına almak için, okul rehberlik servislerince ebeveynlere yönelik suçluluğun nedenleri ile ilgili eğitimler verilmelidir.

Aile ilişkilerini ve ailedeki kişiler arasındaki iletişimi arttırmak için aile iletişim becerileri kazandırmaya yönelik seminerler düzenlenmelidir.

Suça sürüklenen çocukların ebeveyn tutumlarını ve bağlanma stillerini inceleyen çalışmaların ulusal literatürümüzde sayıca az olduğu göze çarpmaktadır. Yapılacak araştırmalarda suça sürüklenen çocuklara yer verilmesi alan yazınına katkı sağlayabilir.

Bu çalışmada suça sürüklenen çocukların ve suça sürüklenmeyen çocukların cinsiyet ayrımı yapmadan ebeveyn tutumları ve bağlanma stilleri incelenmeye çalışılmıştır. Sadece erkek ya da sadece kız gruplarına yönelik araştırma yapılarak cinsiyet farklılıkların araştırma sonuçlarını değiştirip değiştirmediğine bakılması yararlı olabilir.

Farklı sosyo-kültürel yapıda yetişmiş suça sürüklenen çocuklardan örneklem grubu seçilerek, ebeveyn tutumları ve bağlanma stilleri incelenerek, sonuçların farklılığı tartışılabilir. 


\section{KAYNAKÇA}

Akduman, G. G., Akduman, B., \& Cantürk, G. (2007). Ergen suçluluğunda bazı kişisel ve ailesel özelliklerin incelenmesi. Türk Pediatri Arşivi, 42, 156- 161.

Akın, A. (2009). Algılanan anne- baba tutumlarının öğrencilerin sosyal bilgiler dersindeki akademik başarıları üzerine etkisi (Bursa ili örneği). Yüksek Lisans Tezi, Sakarya Üniversitesi Sosyal Bilimler Enstitüsü, Sakarya.

Algan, A. G.,\& Şendil, G. (2013). Okul öncesi çocuklar ve ebeveynlerinin bağlanma güvenlikleri ile çocuk yetiştirme tutumları arasındaki ilişkiler. Psikoloji Çalışmaları Dergisi, 33(1), 55-68.

Balcı, G.P. (2011). Madde kullanım bozukluğu olan ergenlerde çocukluk çă̆ı travmalarının bağlanma ile ilişsisi. Tıpta Uzmanlık Tezi, Sağlık Bakanlığı Bakırköy Prof Dr. Mazhar Osman Ruh Sağlığı ve Sinir Hastalıkları Eğitim ve Araştırma Hastanesi 11. Psikiyatri Birimi, İstanbul.

Balcı, H. (2011). Çocuk suçluluğu ve toplumsal nedenleri. Yüksek Lisasn Tezi, Dumlupınar Üniversitesi Sosyal Bilimler Enstitüsü, Kütahya.

Baltacı, A. (2011). Çocuk Suçluluğu. Doktora Tezi, Ankara Üniversitesi Sosyal Bilimler Enstitüsü, Ankara.

Beijing Kuralları m. 2 (1985). http://cocukhaklari.barobirlik.org.tr/dokuman/ mevzuat_uakararlar/cocukadaletsistemininuygulanmasi.pdf adresinden erişilmiştir.

Bolattekin, A. (2014). Anne-babanın bağlanma stilleri, anna-baba tutumları ve çocuklarındaki davranış problemleri arasındaki ilişkinin incelenmesi. Yüksek Lisans Tezi, İstanbul Arel Üniversitesi Sosyal Bilimler Enstitüsü, İstanbul.

Bowlby, J. (1999). Attachment and lose: Vol. 2. separation: Anxiety and anger. New York: Basic.

Büyüköztürk, Ş., Akgün, Ö., Karadeniz, Ş., Demirel, F., \& Kılıç, E. (2014). Bilimsel araştırma yöntemleri. Ankara: Pegem.

Çocuk Koruma Kanunu (2005). http://www.mevzuat.gov.tr/MevzuatMetin/1.5.5395.pdf

sayfasından erişilmiştir.

Demirli, A. (2013). Algılanan ana baba tutumları, bağlanma boyutları, yalnızlık ve umudun yapısal ilişkileri. Doktora Tezi, Orta Doğu Teknik Üniversitesi Eğitim Bilimleri Enstitüsü, Ankara.

Dirim, A. (2003). Çocuk ruh să̆lı̆̆g. İstanbul: Esin.

Doğan, N. (1990). Çocuk suçluluğu ve çocuk mahkemeleri. Adalet Dergisi 81(1).

Erdoğdu, M. Y. (2005). Suça yönlendirilen ve yönlendirilmeyen çocukların aile ilişkileri ile saldırganlık davtanışlarının karşılaştırılması. Çocuk ve Ruh Sağlı̆̆ Dergisi, 12(3).

Ersin, B. (2010). Lise ögrencilerinin suç eğilimleri ile anne-baba tutumları arasındaki ilişki (Beyoğlu ilçesi örneği). Yüksek Lisans Tezi, Beykent Üniversitesi Sosyal Bilimler Enstitüsü, İstanbul.

Günaydın, G., Selçuk, E., Sümer, N.,\& Uysal, A. (2005). Ebeveyn Ve Arkadaşlara Bağlanma Envanteri Kısa Formu'nun psikometrik açıdan değerlendirilmesi. Türk Psikologlar Derneği Psikoloji Yazıları, 8(16), 13-23. 
Haapasalo, J. \& Pokelo, E. (1999). Child rearing and child abuse antecedents of criminality. Agression and Violent Behavior, 4(1), 107-127.

Işık, G. (2003).Çocuk suçluluğunda ailenin etkileri: Elazığ Islahevi örneği. Yüksek Lisans Tezi, Firat Üniversitesi Sosyal Bilimler Enstitüsü, Elazı ̆̆.

İçli, T. (2004). Türkiye'de suçlular, sosyal kültürel ve ekonomik özellikleri. Ankara: Bizim Büro.

Kesebir, S., Kavzoğlu, S. Ö., \& Üstündağ, M. F. (2011). Bağlanma ve Psikopataloji. Psikiyatride Güncel Yaklaşımlar, 3(2), 321-342.

McCord, J. (1991). Family relationship, juvenile delinquency and adult criminality. Criminology, 29, 398- 417.

Pardini, D. A., Loeber, R. \& Stouthamer, L. M. (2005). Developmental shifts in parent and peer influences on boys' beliefts about delinquent behavior. Journal of Research on Adolescence, 15(3), 299-323.

Sevük, H. Y. (1998). Uluslar arası sözleşmelerdeki ilkeler açısından çocuk suçluluğu ile mücadelede kuramsal yaklaşım. İstanbul: Beta.

Sezer, A., Kolaç, N., \& Erol, S. (2013). Bir İlköğretim okulu 4, 5 ve 6. Sınıf öğrencilerinin saldırganlık düzeylerinin anne-baba tutumları ve bazı değişkenler ile ilişkisi. $M U ̈ S B E D$, 3(4), 184-190.

Sümer, N. \& Güngör, D. (1999). Çocuk yetiştirme stillerinin bağlanma stilleri, benlik değerlendirmeleri, ve yakın ilişkiler üzerindeki etkisi. Türk Psikoloji Dergisi, 14, 35- 58.

Tanış, Z. (2014). Yetişkinlerde bağlanma stilleri ve öfke tarzları arasındaki ilişkinin incelenmesi. Yüksek Lisans Tezi, Haliç Üniversitesi Sosyal Bilimler Enstitüsü, İstanbul.

Tunceroğlu, Z. (2015). Suça sürüklenen çocuklarda mükerrerliğin irdelenmesi. Doktora Tezi, İstanbul Üniversitesi Adli Tıp Enstitüsü, İstanbul.

Türk Dil Kurumu. (2011). Türkçe sözlük. Ankara: TDK.

Türktan, Ş. (2004). İstanbul ili 6. sınıf öğrencilerinin aileye bağlanma düzeyleri ile algılanan özgüvenleri ve okul başarıları arasındaki ilişkiler. Yüksek Lisans Tezi, Marmara Üniversitesi Eğitim Bilimleri Enstitüsü, İstanbul.

Uluğtekin, S. (2005). Çocuk adalet sisteminde sosyal inceleme raporu. Ankara: Dostlar Dayanışma Derneği Ankara Şubesi Yay.

Ward, P. (2010). Children in the 1800's. Boston: Beacon. 